\title{
Are Government Schemes Promoting Women Entrepreneurship?
}

\author{
Deepali Navin Shah, Shrikrishna Mahajan
}

\begin{abstract}
Always the question arises "Why make schemes specially for women?": Women's are one of the most important factor who can help in increasing the acceleration of economic development of a nation. Government of India through various five year plans have continuously implementing programs for including women's in work force participation. Entrepreneurship is another vital factor which is given due importance to promote women entrepreneurship. Various schemes have been implemented based on the requirement of the area to capitalise the resources available and promote women. This study is being conducted in Sangli district in Maharashtra a place which is known as Turmeric city and a district headquarters and a highest sugar producing district. Various schemes offered for women entrepreneurship and its helpfulness is discussed in this paper.

Keywords: Women, Entrepreneurship, Government Schemes, India
\end{abstract}

\section{INTRODUCTION}

Sustained economic growth is the need of this era and is possible only by triggering productive economic activity, wherein equal contribution from women is also expected. Through Ministry of Women and Child development the Government of India in their XII five-year plan have emphasised women to be the agent for economic growth. Their participation in the workforce, the quality of work allotted, self-employment and entrepreneurial activity contributes to the GDP are also the indicators to understand the extent of them being accepted. On all these parameters women in India are far worse than men and the challenge is to bridge the inequality. Due to the opening up of the economic domain and its rapid growth have escalated some of the existing structural barriers faced by women and new challenges in the form of dismantling of traditional support structures, displacement due to migration, obsolescence of traditional skill sets has emerged. An important strategy of financial inclusion in India, particularly for women, has been Micro finance.

Policies are the road maps that guide the government bodies and the other machinery for implementation of programmes that are developmental. In order to develop the women entrepreneurs, the government through a statutory organizations and the Nation empowerment policy have implemented schemes.

Revised Manuscript Received on November 15, 2019.

* Correspondence Author

Ms. Deepali Navin Shah*, Assistant Professor in Institute of Management of Kolhapur, Bharati Vidyapeeth University.

Dr. Shrikrishna, Mahajan Professor in Commerce and Management at Shivaji University Kolhapur

(C) The Authors. Published by Blue Eyes Intelligence Engineering and Sciences Publication (BEIESP). This is an open access article under the CC BY-NC-ND license (http://creativecommons.org/licenses/by-nc-nd/4.0/)
These schemes and programmes are run in the state with help of government agencies and banks. The schemes are plans that are implemented by the government agencies. The state of Maharashtra has designed schemes offer women entrepreneurs on the base of the policy designed by the Government of India. These are the schemes which are implemented by DIC, KVIC KVIB MSME etc.

\section{CONCEPTUAL BACKGROUND}

Acc. to SBA (U.S Small Business Administration) "An entrepreneur is a person who organizes and manages a business undertaking, assuming the risk for the sake of profit".

Entrepreneurship involves decision making, innovation, implementation, forecasting of the future, independency, and success first and this is how entrepreneurship developed Entrepreneurship is a discipline with a knowledge base theory. It is a resultant of complex socio-economic, psychological, technological, legal and other factors.

Women entrepreneur is defined as the one who initiates, organizes and runs a business enterprise. Kamal Singh, a woman entrepreneur from Rajasthan has defined woman entrepreneur as "a confident, innovative and creative woman capable of achieving self-economic independence individually or in collaboration, generates employment opportunity for others through establishing and running the enterprise by keeping pace with her personal, family and social life."

\section{STATEMENT OF THE PROBLEM}

Women constitute 50 percent of human resources. Their contribution plays a vital role in the family as well as in the economic development and social transformation of that sector.

Following are the questions that initiated the present research problem

1) What government is doing for promoting women entrepreneurship?

2) How much are government schemes are helpful for women entrepreneurship?

\section{OBJECTIVE OF THE STUDY}

The objective of the study is to understand the initiatives taken by government to promote women entrepreneurs. This study also tries to evaluate the helpfulness of Government schemes for women entrepreneurship.

\& Sciences Publication 


\section{RESEARCH METHODOLOGY}

The study is being conducted based on the most popular schemes that are working effectively were considered as per the interview with the officers of MAVIM, DUDO and DIC. This was based on the basis of the new schemes framed and replaced during the year 2015. Scheme named Suvarna Jayanti Shahari / Grameen Yojana (SJSRY and SJGRY) was converted in to National Rural / Urban Livelihood Mission (NRLM / NULM) which combined called as Maharashtra State Rural Livelihood Mission (MSRLM). Another scheme under MAVIM titled Ramai Mahila Sakshamikaran Yojana was replaced by Tejaswini Scheme. A new scheme by DUDA/DRDA with MAVIM introduced Community Management Resource Centre (CMRC) was introduced in several locations of Sangli district. Thus the schemes that are fully working in Sangli District were considered.

To understand the effectiveness of these schemes samples from the most popular schemes working effectively in Sangli District were identified. With the help of compound average growth rate of every individual the growth of the women is identified first and then the scheme that supported is been identified.

\section{MAHILA ARTHIK VIKAS MAHAMANDAL}

One of the most effective agency formed for reaching the women population is through Mahila Arthik Vikas Mahamandal (MAVIM) placed in 34 districts of Maharashtra is the State Women's Development Corporation of Government of Maharashtra. The Mission behind the formation of MAVIM is to bring in gender justice and equality for women by investing in human capital and capacity building of women through SHG's. Thus making them economically and socially empowered and enabling them to access sustainable livelihoods. It bridges the gap between the employment opportunities available for women and creates market linkages for sustainable development of women. It works with the inclusion of the women selected from these villages called Sahayoginis. There are 35 to 40 Sahayoginies who work at the ground level to support around 30 to 40 SHG's individually by covering 8 to 10 villages in the stipulated taluka. They are responsible for providing the basic capacity building, training inputs to SHG members depending upon their demographic factors and level of maturity to nurture them effectively.

The various schemes implemented by MAVIM are Tejaswini Maharashtra Rural Women Empowerment Program, Minority Women Empowerment Program (MWEP), 4\% Low interest rate scheme, Convergence of Agricultural Interventions in Maharashtra (CAIM), Skill Training for Women, Maharashtra State Rural Livelihood Mission (MSLRM), Integrated Watershed Management Program (IWMP).

\section{COMMUNITY MANAGED RESOURCE CENTRE}

Community Managed Resource Centre (CMRC) is a federation of around 150-200 SHGs formed in a cluster of around twenty villages, within the radius of 20 to $25 \mathrm{~km}$. All SHGs in the cluster, regardless of the agency that promoted them, they are eligible to become members and avail the services of CMRC. The CMRC'S are functioning with an extensive and holistic agenda for development and to provide the basic primary services to SHGs. Activities like capacity building, training to members, bank linkages, gradation and audit of SHGs are performed. CMRC's also provide specialized services to SHGs such as assessing the livelihood needs, tapping the required resources through convergence with various government schemes, services and enable community development program.

MAVIM supports CMRCs in its initial period which then gradually decreases its support and allows CMRC to work independently. Thus SHGs make a contribution for the effective performance of CMRC right from the beginning. It is expected that CMRCs gradually becomes self-reliant from fourth year of their establishment.

Right now CMRCs are active in six talukas (Miraj, Kavte Mahankal, Jath, Tasgaon, Shirala and Unklekop) of Sangli district. These CMRC's are given a unique name for identification and for motivating the women members for becoming self-reliant. The name under which CMRC works in Miraj area is Navprabha. Likewise, Kavte Mahankal is termed as Parivarthan. The CMRC in Jath are is named as Kranti, Tasgaon with Suvedha, Shirala is namedas Bhagyoday and Unklekop is named as Savitri. The CMRCs first identify the business that be empowered in that particular village by going in to the history, availability of resources and the skill set available there. Later with which village ladies are selected at executive bodies who are designated as Sahayoginies. These Sahayoginies are assigned 6 to 7 villages where through their communication and various training obtained from the officers of CMRC try to influence the women to opt for business to utilize her free time. These Sahayoginies report the CMRC on a monthly meeting held between 1 to 4 days of the months starting. Thus CMRC not only provide them the training for that business but also give service throughout the period for effective running of the business as well as to provide timely help to the needy. This helps the women in gaining confidence to accept the business and run it efficiently and return back the benefit obtained. They are normally provided with 3 years' incubation time later which they start to repay the benefits obtained. As per the interviews with the CMRCs head, with in the period of three years they have obtained more than $50 \%$ of the invested amount. The assistance is provided through the intermediary's like ICICI and Dena bank. The amount provided is six times more than the amount based on the savings done through their SHG or a maximum of 2 lakhs is given. Thus these CMRC generate their income by charging $2 \%$ from the benefitted bank through loan and a yearly service of charge according to the number of years working. The business suggested by CMRCs is $70 \%$ farming or agro oriented business and $30 \%$ others as per the skill set.

\section{SUVARNA JAYANTI ROZGAR YOJANA (SJRY)}

This is a centrally sponsored scheme which came into effect on 1 December 1997. The scheme strives to provide gainful employment to the urban unemployed and underemployed poor, through encouraging the setting up of self-employment ventures by the urban poor living below the poverty line.

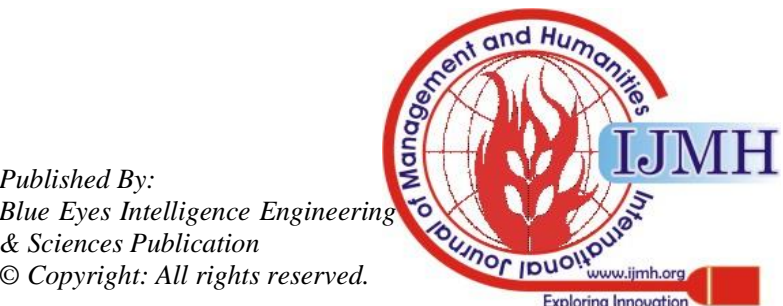


SJRY seeks to provide gainful employment to the rural and urban poor (living below poverty line) unemployed or under-employed, through setting up of self-employment ventures or provision of wage employment.

The growth of SJRY scheme in the past five years can be understood. Here it can be noted that the amount sanctioned to female members is comparatively low as compared with the male counterparts. Except for the year 2013-14 the amount sanctioned is lower than $50 \%$ for female members. The scheme is helpful for those who are from urban and poor below poverty line. Thus it creates a hindrance for those women who don't come under poverty line but wants to start up a venture for upgrading her standard of living. This scheme is further merged in to MSRLM from the year 2014 onwards.

\section{MAHARASHTRA STATE LIVELIHOOD MISSION (MSRLM)}

The Maharashtra State Rural Livelihoods Mission (MSRLM) was launched on July 2011 as a registered organization under the aegis of the National Rural Livelihoods Mission (NRLM) - Aajeevika - endeavours to impact rural poverty through a range of extensive and strategic livelihoods interference in a time bound manner. This program aims at eradication of rural poverty by building sustainable institutions of poor and ultimately leading them to sustainable livelihoods. The MSRLM program goes beyond income generation activities and employment programs to include capacity building, financial inclusion, social mobilization and marketing services as equally important elements of livelihoods enhancement.

Table 1 Taluka Wise Progress Report of all the MSRLM Scheme

\begin{tabular}{|c|c|c|c|c|c|c|c|c|c|c|c|c|c|c|c|c|}
\hline \multicolumn{15}{|c|}{ Maharashtra State Rural Livelihood Mission Progress } & \multicolumn{2}{|c|}{ March 2017} \\
\hline \multicolumn{11}{|c|}{ 2016-2017 PUNE Division } & \multicolumn{6}{|c|}{ Sangli district } \\
\hline \multirow{2}{*}{$\begin{array}{c}\text { S } \\
\text { no }\end{array}$} & \multirow{2}{*}{ Taluka } & \multicolumn{6}{|c|}{ Bank Linkage } & \multicolumn{3}{|c|}{$\begin{array}{c}\text { Jan Dhan SHGs } \\
\text { (Individual Bank } \\
\text { Account) }\end{array}$} & \multicolumn{3}{|c|}{ ODF SHGs } & \multicolumn{3}{|c|}{$\begin{array}{c}\text { No of SHGs member } \\
\text { got job card under } \\
\text { MGNREGS }\end{array}$} \\
\hline & & $\begin{array}{l}\text { Tar } \\
\text { get }\end{array}$ & $\begin{array}{l}\text { Ahie } \\
\text { v }\end{array}$ & $\%$ & Target & Ahiev & $\%$ & $\begin{array}{l}\text { Ta } \\
\text { rge } \\
\text { t }\end{array}$ & Ahiev & $\%$ & $\begin{array}{l}\text { Targe } \\
\text { t }\end{array}$ & $\begin{array}{l}\text { Ahie } \\
\text { v }\end{array}$ & $\%$ & $\begin{array}{l}\text { Targe } \\
\text { t }\end{array}$ & Ahiev & $\%$ \\
\hline 1 & Miraj & 298 & 62 & 21 & 525.17 & 78.07 & 15 & 76 & 77 & 101 & 836 & 860 & 103 & 1021 & 1023 & 100 \\
\hline 2 & $\begin{array}{l}\text { Tasgao } \\
\mathrm{n}\end{array}$ & 180 & 61 & 34 & 317.21 & 73.15 & 23 & 76 & 82 & 108 & 836 & 839 & 100 & 1021 & 1022 & 100 \\
\hline 3 & $\begin{array}{l}\text { Khana } \\
\text { pur }\end{array}$ & 138 & 37 & 27 & 243.20 & 38.70 & 16 & 76 & 80 & 105 & 836 & 930 & 111 & 1020 & 1080 & 106 \\
\hline 4 & Atpadi & 138 & 45 & 33 & 243.20 & 66.52 & 27 & 76 & 78 & 103 & 836 & 840 & 100 & 1021 & 1021 & 100 \\
\hline 5 & Jath & 175 & 45 & 26 & 308.40 & 70.40 & 23 & 76 & 76 & 100 & 836 & 1506 & 180 & 1021 & 1043 & 102 \\
\hline 6 & $\begin{array}{l}\text { K } \\
\text { Mahan }\end{array}$ & 173 & 63 & 36 & 304.88 & 77.30 & 25 & 76 & 76 & 100 & 836 & 836 & 100 & 1020 & 1021 & 100 \\
\hline 7 & Walwa & 298 & 106 & 36 & 525.16 & 110.8 & 21 & 76 & 76 & 100 & 836 & 836 & 100 & 1021 & 1021 & 100 \\
\hline 8 & Shirala & 155 & 14 & 9 & 273.16 & 18.0 & 7 & 76 & 76 & 100 & 836 & 836 & 100 & 1020 & 1022 & 100 \\
\hline 9 & Palus & 155 & 46 & 30 & 273.16 & 76.10 & 28 & 76 & 84 & 111 & 836 & 843 & 101 & 1021 & 1022 & 100 \\
\hline 10 & $\begin{array}{l}\text { Kadega } \\
\text { on }\end{array}$ & 155 & 33 & 21 & 273.16 & 32.35 & 12 & 76 & 126 & 166 & 836 & 836 & 100 & 1020 & 1022 & 100 \\
\hline \multicolumn{2}{|c|}{ Mavim } & & 1065 & & & 2130.8 & & & 0 & & & 0 & & & & \\
\hline \multicolumn{2}{|c|}{ Total } & 1865 & 1577 & 85 & 3286.7 & 2772.2 & 84 & 760 & 831 & 109 & 8360 & 9162 & 110 & 10206 & 10297 & 101 \\
\hline
\end{tabular}

Souce: DRDO Sangli

MAVIM had entered into an MOU with MSRLM from 17th April 2013. MAVIM is engaged as an implementation and technical partner MSRLM in 6 Block of 3 district Thane (Bhivandi, Shahapur), Solapur (Malshiraj, Mohal) and Gondia (Salekasa, Tiroda). MAVIM thus supports 295 villages and 1972 existing SHGs and will expand in 694 villages in upcoming 3 years, which will be implemented on Sahayogini model. 
Are Government Schemes Promoting Women Entrepreneurship?

Table 2 Taluka Wise Progress Report of all the benefits provided under MSRLM Scheme

\begin{tabular}{|c|c|c|c|c|c|c|c|c|c|c|c|c|c|c|c|c|}
\hline \multirow{2}{*}{$\begin{array}{l}\mathbf{S} \\
\mathbf{N} \\
\mathbf{0}\end{array}$} & \multirow{2}{*}{$\begin{array}{l}\text { Talu } \\
\text { ka }\end{array}$} & \multicolumn{3}{|c|}{ NSAP } & \multicolumn{3}{|c|}{ PMSBY } & \multicolumn{3}{|c|}{ PMJJBY } & \multicolumn{3}{|c|}{ NREGA } & \multicolumn{3}{|c|}{ R-Seti } \\
\hline & & $\begin{array}{l}\text { Targe } \\
\text { t }\end{array}$ & Ahiev & $\%$ & $\begin{array}{l}\text { Targ } \\
\text { et }\end{array}$ & Ahiev & $\%$ & $\begin{array}{l}\text { Tar } \\
\text { get }\end{array}$ & Ahiev & $\%$ & $\begin{array}{l}\text { Targe } \\
\text { t }\end{array}$ & $\begin{array}{l}\text { Ahie } \\
\text { v }\end{array}$ & $\%$ & $\begin{array}{l}\text { Targe } \\
\text { t }\end{array}$ & $\begin{array}{l}\text { Ahie } \\
\text { v }\end{array}$ & $\%$ \\
\hline 1 & Miraj & 100 & 102 & 102 & 836 & 842 & 101 & 836 & 839 & 100 & 511 & 514 & 101 & 79 & 111 & 141 \\
\hline 2 & $\begin{array}{l}\text { Tasga } \\
\text { on }\end{array}$ & 100 & 102 & 102 & 836 & 841 & 101 & 836 & 844 & 101 & 510 & 511 & 100 & 49 & 89 & 182 \\
\hline 3 & $\begin{array}{l}\text { Khan } \\
\text { apur }\end{array}$ & 100 & 102 & 102 & 836 & 854 & 102 & 836 & 841 & 101 & 510 & 565 & 111 & 33 & 30 & 91 \\
\hline 4 & $\begin{array}{l}\text { Atpa } \\
\text { di }\end{array}$ & 100 & 106 & 106 & 836 & 840 & 100 & 836 & 839 & 100 & 510 & 582 & 114 & 33 & 82 & 248 \\
\hline 5 & Jath & 100 & 128 & 128 & 836 & 842 & 101 & 836 & 842 & 101 & 510 & 717 & 141 & 72 & 55 & 76 \\
\hline 6 & $\begin{array}{l}\mathrm{K} \\
\text { Maha } \\
\mathrm{n}\end{array}$ & 100 & 100 & 100 & 836 & 836 & 100 & 836 & 836 & 100 & 510 & 511 & 100 & 39 & 33 & 85 \\
\hline 7 & $\begin{array}{l}\text { Walw } \\
\text { a }\end{array}$ & 100 & 100 & 100 & 836 & 836 & 100 & 836 & 836 & 100 & 511 & 511 & 100 & 79 & 69 & 87 \\
\hline 8 & $\begin{array}{l}\text { Shiral } \\
\mathrm{a}\end{array}$ & 100 & 100 & 100 & 836 & 836 & 100 & 836 & 836 & 100 & 510 & 460 & 90 & 39 & 31 & 79 \\
\hline 9 & Palus & 100 & 101 & 101 & 836 & 842 & 101 & 836 & 851 & 102 & 511 & 513 & 100 & 39 & 38 & 97 \\
\hline 10 & $\begin{array}{l}\text { Kade } \\
\text { gaon }\end{array}$ & 100 & 106 & 106 & 836 & 837 & 100 & 836 & 840 & 100 & 510 & 511 & 100 & 33 & 30 & 91 \\
\hline \multicolumn{2}{|c|}{ Total } & 1000 & 1047 & 105 & 8360 & 8406 & 101 & 8360 & 8404 & 101 & 5103 & 5395 & 106 & 495 & 568 & 115 \\
\hline
\end{tabular}

Souce: DRDO Sangli

In this model it can be observed that various programs are jointly held like linking every member by opening a bank account, Jan Dhan program. SHG members were provided with job cards under MGNREGS. Efficiently running various plans like National Social Assistance program (NSAP), Pradhan Mantri Suraksha Bima Yojana (PMSBY), Pradhan Mantri Jeevan Jyoti Bima Yojana (PMJJBY), National Rural Employment Guarantee Act (NREGA) and Rural Self Employment Training Institute (R-SETI).

\section{PRIME MINISTER EMPLOYMENT GENERATION PROGRAMME (PMEGP)}

Prime Minister's Employment Generation Programme (PMEGP) is a centrally sponsored programme implemented by the State government for the introduction of a new credit linked subsidy programme. It is a merging of two schemes that were in operation till 2008 namely Prime Ministers Rojgar Yojana (PMRY) and Rural Employment Generation Programme (REGP) for generation of employment opportunities through establishment of micro enterprises in rural as well as urban areas. The main objectives of this programme are to generate employment opportunities through setting up of new self-employment ventures of traditional artisans / unemployed youths to reduce migration to urban areas.

Table 3 Gender Wise Loan Sanctioned under PMEGP

\begin{tabular}{|c|c|c|c|c|c|c|}
\hline \multirow{2}{*}{ S No } & \multirow{2}{*}{ Year } & \multirow{2}{*}{$\begin{array}{l}\text { No of loans } \\
\text { sanctioned }\end{array}$} & \multicolumn{2}{|c|}{ Gender } & \multicolumn{2}{|c|}{ Percentage } \\
\hline & & & Male & Female & $\%$ of Male & \% of Female \\
\hline 1 & 2008-2009 & 14 & 9 & 5 & $64 \%$ & $36 \%$ \\
\hline 2 & $2009-2010$ & 116 & 59 & 57 & $51 \%$ & $49 \%$ \\
\hline 3 & $2010-2011$ & 41 & 25 & 16 & $61 \%$ & $39 \%$ \\
\hline 4 & 2011-2012 & 20 & 14 & 6 & $70 \%$ & $30 \%$ \\
\hline
\end{tabular}




\begin{tabular}{|c|c|c|c|c|c|c|}
\hline 5 & $2012-2013$ & 55 & 39 & 16 & $71 \%$ & $29 \%$ \\
\hline 6 & $2013-2014$ & 43 & 28 & 15 & $65 \%$ & $35 \%$ \\
\hline 7 & $2014-2015$ & 51 & 38 & 13 & $75 \%$ & $25 \%$ \\
\hline 8 & $2015-2016$ & 50 & 41 & 9 & $82 \%$ & $18 \%$ \\
\hline 9 & $2016-2017$ & 73 & 48 & 25 & $66 \%$ & $34 \%$ \\
\hline 10 & $2017-2018$ & 87 & 47 & 40 & $54 \%$ & $46 \%$ \\
\hline 11 & $2018-2019$ & 64 & 46 & 18 & $72 \%$ & $28 \%$ \\
\hline
\end{tabular}

Source: DIC, Udyog Bhawan, Sangli.

The information stated in Table 3 is collected from DIC Sangli region, which is responsible for providing loan approved by central government for the persons who want to opt for self-employment. In year wise loan sanctioned details can be observed for the year 2008 to 2015 . Where for the year 2008-09 the number of loan sanctioned are 14, in which male $64 \%$ and $36 \%$ of loan was sanctioned to female members. Likewise, a sudden rise can be seen in the year 2009-10 where number of loan sanctioned is 116 with $51 \%$ male and $49 \%$ of female members respectively. For the 2010-11 there is a sudden fall in number with only 41 loans sanctioned where male constitute $61 \%$ and female with $39 \%$. Sanctioned loan percentage for the year 2011-12 still a fall in loan availing members can be seen with 20 loans sanctioned where male percentage is $70 \%$ and female with $30 \%$ of loan sanctioned. Likewise, for the year 2012-13 the number of loan sanctioned were 55 with $71 \%$ loan approved for male members and $29 \%$ with female members is observed. In the year 2013-14 the number of loan sanctioned is 43 with $65 \%$ of male and $35 \%$ of female member. Likewise, in the year 2014-15 the total number of beneficiaries increased to a total of 51 constituting $75 \%$ male and $25 \%$ of female members. In the 2015-2016 the total number of loan sanctioned is 50 out of which $18 \%$ are only female beneficiaries and $82 \%$ are male beneficiaries. In the year 2016-2017 the total number of loan sanctioned were 73 out of which $34 \%$ are female beneficiaries and $66 \%$ are male beneficiaries. From the year 2017-2018 the total numbers of beneficiaries are 87 , out of which $46 \%$ are female and 54\% are male members. In the 2018-2019 the total number of beneficiaries is 64 , out of which $28 \%$ are female and $72 \%$ are male beneficiaries. From the Table 3 data it can be inferred that the number of loan sanctioned is very less for female members as compared to male members.

SEED MONEY SCHEME (SMS)

Seed Money Scheme (SMS) is the scheme which is a part of Prime Minister's Employment Generation Programme (PMEGP). The scheme is active in Maharashtra State where under the scheme unemployed youths are motivated to take up self-employment as their earning source. It provides soft loans to these unemployed individual so that they can share the expenses and have a good start in their business. The repayment policies are also very affordable which does not create a burden on the beneficiaries.

Table 4 Gender wise Loan Sanctioned under SMS Scheme

\begin{tabular}{|c|c|c|c|c|c|c|c|c|c|}
\hline S No & Year & $\begin{array}{l}\text { No of } \\
\text { Loan } \\
\text { Sanctio } \\
\text { ned }\end{array}$ & $\begin{array}{l}\text { Total Amount } \\
\text { of loan } \\
\text { sanctioned }\end{array}$ & $\begin{array}{l}\text { No of } \\
\text { Male }\end{array}$ & $\begin{array}{l}\text { Amount } \\
\text { sanctioned } \\
\text { to male } \\
\text { members }\end{array}$ & $\begin{array}{c}\% \text { of loan } \\
\text { sanctioned }\end{array}$ & $\begin{array}{c}\text { No of } \\
\text { Femal } \\
\text { e }\end{array}$ & $\begin{array}{c}\text { Amount } \\
\text { sanctioned to } \\
\text { female } \\
\text { members }\end{array}$ & $\begin{array}{c}\% \text { of loan } \\
\text { sanctioned }\end{array}$ \\
\hline 1 & 1994-1995 & 30 & 1049886 & 27 & 963065 & $91.73 \%$ & 3 & 86821 & $8.26 \%$ \\
\hline 2 & 1995-1996 & 26 & 1177132 & 24 & 1133632 & $96.3 \%$ & 2 & 43500 & $3.69 \%$ \\
\hline 4 & 1997-1998 & 32 & 1210938 & 26 & 1048421 & $86.57 \%$ & 6 & 162517 & $13.4 \%$ \\
\hline 5 & 1998-1999 & 15 & 966646 & 13 & 872366 & $90.24 \%$ & 2 & 94280 & $9.75 \%$ \\
\hline 6 & 1999-2000 & 7 & 386586 & 6 & 236586 & $61.19 \%$ & 1 & 150000 & $38.8 \%$ \\
\hline 7 & $2000-2001$ & 14 & 863408 & 14 & 863408 & $100 \%$ & 0 & 0 & $0 \%$ \\
\hline 8 & 2001-2002 & 11 & 878791 & 10 & 743536 & $84.6 \%$ & 1 & 135255 & $15.39 \%$ \\
\hline 9 & $2002-2003$ & 12 & 447650 & 11 & 311350 & $69.55 \%$ & 1 & 136300 & $30.44 \%$ \\
\hline 10 & 2003-2004 & 8 & 482230 & 7 & 417230 & $86.52 \%$ & 1 & 65000 & $13.47 \%$ \\
\hline 11 & 2004-2005 & 6 & 353123 & 6 & 353123 & $100 \%$ & 0 & 0 & $0 \%$ \\
\hline 13 & 2006-2007 & 6 & 216892 & 4 & 124392 & $57.35 \%$ & 2 & 92500 & $42.64 \%$ \\
\hline 14 & 2007-2008 & 10 & 2388899 & 9 & 2169107 & $90.79 \%$ & 1 & 219792 & $9.2 \%$ \\
\hline 15 & 2008-2009 & 2 & 75852 & 2 & 75852 & $100 \%$ & 0 & 0 & $0 \%$ \\
\hline 16 & 2009-2010 & 17 & 1162971 & 13 & 1074721 & $92.41 \%$ & 4 & 88250 & $7.58 \%$ \\
\hline 17 & $2010-2011$ & 11 & 1063768 & 10 & 913768 & $85.89 \%$ & 1 & 150000 & $14.10 \%$ \\
\hline 18 & 2011-2012 & 20 & 3209951 & 19 & 3179951 & $99.06 \%$ & 1 & 30000 & $0.93 \%$ \\
\hline
\end{tabular}


Are Government Schemes Promoting Women Entrepreneurship?

\begin{tabular}{|r|r|r|r|r|r|r|r|r|r|}
\hline 19 & $2012-2013$ & 44 & 3874650 & 35 & 2858950 & $73.78 \%$ & 9 & 1015700 & $26.21 \%$ \\
\hline 20 & $2013-2014$ & 34 & 4377195 & 29 & 3343437 & $76.38 \%$ & 5 & 1033758 & $23.61 \%$ \\
\hline 21 & $2014-2015$ & 35 & 6036125 & 27 & 4433025 & $73 \%$ & 8 & 1603100 & $27 \%$ \\
\hline 22 & $2015-2016$ & 34 & 1517578 & 33 & 1377638 & $91 \%$ & 3 & 139940 & $96 \%$ \\
\hline 23 & $2016-2017$ & 40 & 3860000 & 37 & 3337500 & 3 & 522500 & $14 \%$ \\
\hline 24 & $2017-2018$ & 37 & 2980000 & 30 & 2775000 & $93 \%$ & 4 & 205000 & $7 \%$ \\
\hline
\end{tabular}

Source: DIC, Udyog Bhawan, Sangli

\section{JOINT LIABILITY GROUP (JLG)}

JLG is another plan introduced in the year 2014-15 by DCC Bank Ltd Sangli, which in this short period of time has proved following results. According to the opinion of lead bank manager DCC Sangli has around $75 \%$ of hold in Sangli for its effectiveness for the disbursal of loans under various schemes.

A Joint Liability Group is an informal group consisting of 410 individuals coming together for availing bank loan individually or in group with mutual guarantee.

\section{Maharashtra Centre For Entrepreneurship Development}

MCED is a training institute to empower unemployed youth in the district by providing training and encouragement for undergoing self-employment activity through government schemes. "Training for Excellence" is the motto of MCED. For attain sustainable in the area of entrepreneurship develop plan, provide and monitor services. The focus of MCED is to provide quality services, optimum utilization of resources, delivery promptness, skill of trainer's employees and quality management system to enhance satisfaction of the beneficiaries.

MCED is considered to be one of the important aspect, as it is the institution that reaches to the rural people in villages and trains them accordingly. First with the help of its coordinators they identify the need and according to the need of the village and people prepare batch of around 30 for the training purpose. The training is conducted in talukas, so that it becomes easy for the people from every village of that taluka to easily attend the training and get benefitted. Later which the interested members are assisted for availing the loan from DIC and work accordingly.

Table 5 Year wise Status of Participants after attaining the training program

\begin{tabular}{|c|c|c|c|c|c|c|c|c|}
\hline $\mathbf{T}$ & Year & $\begin{array}{l}\text { Total } \\
\text { Number of } \\
\text { Participants } \\
\text { Trained } \\
\end{array}$ & $\begin{array}{l}\text { Total } \\
\text { Number of } \\
\text { Self } \\
\text { Employment } \\
\text { after the } \\
\text { training }\end{array}$ & $\%$ & $\begin{array}{l}\text { Total } \\
\text { Number } \\
\text { of } \\
\text { Employed } \\
\text { in a } \\
\text { company } \\
\text { after the } \\
\text { Training } \\
\end{array}$ & $\%$ & $\begin{array}{l}\text { Total } \\
\text { Number } \\
\text { of Un } \\
\text { employed } \\
\text { after the } \\
\text { training } \\
\text { program }\end{array}$ & $\%$ \\
\hline 1 & 2008-2009 & 0 & 0 & 0 & 0 & 0 & 0 & 0 \\
\hline 2 & 2009-2010 & 488 & 167 & $34 \%$ & 34 & $7 \%$ & 287 & $59 \%$ \\
\hline 3 & $2010-2011$ & 424 & 127 & $30 \%$ & 52 & $12 \%$ & 245 & $58 \%$ \\
\hline 4 & 2011-2012 & 123 & 30 & $24 \%$ & 14 & $11 \%$ & 79 & $64 \%$ \\
\hline 5 & 2012-2013 & 203 & 103 & $51 \%$ & 2 & $1 \%$ & 98 & $48 \%$ \\
\hline 6 & 2013-2014 & 284 & 97 & $34 \%$ & 160 & $56 \%$ & 27 & $10 \%$ \\
\hline 7 & 2014-2015 & 444 & 78 & $17 \%$ & 167 & $38 \%$ & 199 & $45 \%$ \\
\hline 8 & 2015-2016 & 214 & 38 & $17 \%$ & 119 & $56 \%$ & 57 & $27 \%$ \\
\hline \multirow[t]{2}{*}{9} & 2016-2017 & 224 & 12 & $5 \%$ & 24 & $11 \%$ & 188 & $84 \%$ \\
\hline & Total & 2185 & 497 & $23 \%$ & 620 & $28 \%$ & 1068 & $49 \%$ \\
\hline
\end{tabular}

Table 6 Training of Women Participants

\begin{tabular}{|c|r|r|}
\hline Particulars & $\begin{array}{c}\text { Women } \\
\text { Beneficiaries }\end{array}$ & Percentage \\
\hline Self-Employed & 497 & $22.7 \%$ \\
\hline Employed & 620 & $28 \%$ \\
\hline Unemployment & 1068 & $48.8 \%$ \\
\hline Total no of Participants Trained & 2185 & $100 \%$ \\
\hline
\end{tabular}

Around 22\% have been benefitted by the training program who have started with self-employment. 28\% through the training has started working under others and $48 \%$ of the members are still unemployed.

\section{Effectiveness of Government Scheme}

To understand the effectiveness of the scheme, women undergoing entrepreneurship were identified. Government at different points have come up with various schemes to provide a helping hand to improve the standard of living.
These women have thus opted various schemes at some of time in their business either at the initial start phase or in middle of business as per their potential of the business. The various schemes that found to be very active in the study area were MSRLM, CMRC, PMEGP, MUDRA, SJRY, SHG etc. 
who with varied objectives work in different areas of the district to reach people and provide support as much as possible. The sample obtained is as follows:

Table 7 Government Schemes Opted

\begin{tabular}{|c|l|c|r|}
\hline S. No & Particulars & Frequency & Percentage \\
\hline 1 & CMRC & 102 & 22 \\
\hline 2 & MSRLM & 102 & 22 \\
\hline 3 & MUDRA & 54 & 12 \\
\hline 4 & PMEGP & 101 & 22 \\
\hline 5 & SJRY & 50 & 11 \\
\hline 6 & SHG & 29 & 6 \\
\hline 7 & SMS & 30 & 100 \\
\hline & & & \\
\hline
\end{tabular}

Note:

CMRC: Community Management Resource Centre

MSRLM: Maharashtra State Rural Livelihood Mission

MUDRA: Micro Units Development and Refinance Agency

PMEGP : Prime Minister Employment Generations Program

SJRY : Suvarna Jayanti Rojgar Yojana

SHG : Self Help Group

It can be observed that various agencies which support as per their objective set to help women entrepreneurs. As per the area covered (urban/rural), as per its motto (central/state) government and by understanding the number forecasted by the lead bank for the forth coming year the sample respondents from every agency were opted as sample. Thus out of 468 respondents 102 respondents were the beneficiaries from CMRC, MSRLM; PMEGP (101); Mudra (54); SJRY (50); SHG (29) and SMS (30) were selected.

Table 8 Helpfulness of the Scheme

\begin{tabular}{|c|l|c|r|}
\hline S. No & \multicolumn{1}{|c|}{ Particulars } & Frequency & Percentage \\
\hline 1 & Highly Helpful & 212 & 45 \\
\hline 2 & Somewhat Helpful & 154 & 17 \\
\hline 3 & Helpful & 79 & 2 \\
\hline 4 & Less Helpful & 11 & 3 \\
\hline 5 & Not at all helpful & 12 & 100 \\
\hline
\end{tabular}

Source: Field Survey

Note: Percentage has been rounded off.

The opinion of female beneficiaries about the helpfulness of the scheme is $45 \%$ opined these schemes were highly helpful for them to start with their venture, 33\% of respondents opined the helpfulness to some extent, $17 \%$ opined helpful, $2 \%$ of the respondents opined less helpful and 3\% opined not at all helpful. Thus it can be inferred that
Source: Compiled by Researcher

SMS : Seed Money Scheme

maximum respondents felt scheme has helped them in pursuing entrepreneurship.

\section{CONCLUSION}

Entrepreneurship is the core requirement for having economic development in a region. This gets dual acceleration when women participate in the process. To get the involvement of women and to create a conducive environment for women to start with entrepreneurship government is continuously taking steps. Various schemes are launched by central and state government as per the requirement of that particular place so that resources are used to its optimum level. The women having skill but no support from their family and the one who lack in confidence are benefitted through these schemes. The schemes provide all sorts of support to these women entrepreneurs to pursue entrepreneurship and continue it for the wellbeing of self and for the nation.

\section{REFERENCES}

1. Annual Report Bank of India-Lead Bank Sangli year 2012-13 to 2015-2016

2. Anis Md Zohurul and Hasan Md Mehedi (2013), Women Entrepreneurs of Small and Medium Enterprises in Rajshahi Area: Opportunities and Challenges, International Journal of Scientific and Research Publications, ISSN 2250-3153 Volume 3, Issue 8, August 2013.

3. Bose Vinisha (2012), An Analytical Study of the Impact of Women Entrepreneurship Development Measures Promoted by the Government and Financial Institutions in Kerala, Mahatma Gandhi University, Kottayam.

4. Dave Vina D (2014), Women Entrepreneurship Development (Special reference to Ahmedabad City), Sardar Patel University, Gujarat.

5. Census Report of India, Government of India, New Delhi, 2011

6. https://en.wikipedia.org/wiki/Maharashtra

7. https://sangli.nic.in/district-profile/

8. http://www.nrlmskills.in/ProgramStatus.aspx

9. http://di.maharashtra.gov.in/_layouts/15/DOIStaticSite/English/downl oads.html\#tag9

10. http://www.livemint.com/Politics/RNbm83ry0nzmmTXeHizAmI/Wo men-SHGs-to-get-loans-at-lower-rates.html NEWS

11. https://www.epw.in/engage/article/Survey-at-an-IIT-Campus-ShowsHow-Caste-Affects-Students-Perceptions

12. https://mahades.maharashtra.gov.in/files/publication/ESM 17 18 en g.pdf

13. http://www.aeaweb.org/articles.php?doi=10.1257/aer.100.2.125

14. http://demos.masterequation.com/drda/index.php/drda

\section{AUTHORS PROFILE}

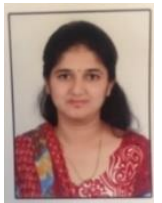

Ms. Deepali Navin Shah, has been conferred with degree MBA., M.Phil. and currently pursuing $\mathrm{Ph}$. D. She is working as Assistant Professor in Institute of Management of Kolhapur, Bharati Vidyapeeth University. She is working on the research to identify the government support to women entrepreneurship in Sangli district. She has participated in conference held in Gaeddu College of Business Studies, Royal University of Bhutan on the topic "Rural Development in Bhutan: Prospects and Challenges". She has published two study material for Bharati Vidyapeeth School of Distance education.

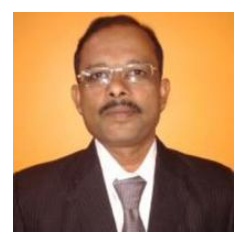

Dr. Shrikrishna Mahajan, has been conferred with degrees M. Com., M. Phil. and Ph. D. He is former Head of the Department. At present he is Professor in Commerce and Management at Shivaji University Kolhapur. His research interest is in accounting, finance and rural management areas. He has completed his doctoral work on Disinvestment in Public Sector Undertakings in India. Published By: $\quad \sum_{0}^{0}(1)$ IJIM Blue Eyes Intelligence Engineering \& Sciences Publication 


\section{Are Government Schemes Promoting Women Entrepreneurship?}

He has completed research projects on Entrepreneurial Finance which was funded by UGC and on Financial Inclusion which was funded by ICSSR New Delhi. He is now working on another project of financial inclusion entitled as 'Evaluation of PMJDY: A Road Ahead' which is funded by ICSSR under its IMPRESS scheme. He is also working on accounting policies, financial reporting, social performance reporting and entrepreneurship development etc. He is also looking after the reputed chair called The United Western Bank's Late R. N. Godbole Chair in Financial Management and Banking Research. He has published 47 research papers in reputed journals. He has authored and edited 12 books. 